\title{
Extent and Impact of Women Labor Unemployment in Agriculture and the Alternative Sources of Employment: An Economic Analysis, In Allahabad District of Uttar Pradesh
}

\author{
Ali Ahmad ${ }^{1}$, Dr. Dinesh Kumar ${ }^{2}$ \\ ${ }^{1}$ M.Sc Scholar \\ aada.aliahmad@gmail.com \\ ${ }^{2}$ Associate Professor
}

Department of Agricultural Economics \& Agri-business Management, Allahabad School of Agriculture, Sam Higginbottom Institute of Agriculture, Technology and Sciences, (Formerly Allahabad Agricultural Institute) Deemed-to-be-University, Allahabad-211007, Uttar Pradesh, India

\begin{abstract}
The present study on 'Extent and impact of women labor in agriculture-An economic analysis' was conducted in Chaka block, Allahabad district of Uttar Pradesh state during 2014. A total of 30 women agricultural laborers were selected using multistage random sampling technique from six villages of Chaka block, namely Chak Hiranand, Baswar, Chaka, Barika, Mohabatganj Uparhar and Sandwa Kalan for collecting the required information. The data's were collected from the respondents by personal interview method and it included general information, their season wise employment and unemployment days in agriculture, the pattern and composition of employment, the impact of off season unemployment etc. For the purpose of achieving the specific objectives of the study tabular presentation method with averages and percentages was employed. The results of the study showed that they received wages in cash for all operations except harvest and post harvest operations. They worked for 7-8 hours a day. The women laborers had maximum unemployed days in Zaid (110.04 days) as this is the off season for agriculture in the study area. The lack of employment opportunities in agriculture during off season compelled the women laborers to seek alternative employment sources like NREGS activities, domestic work, construction works, tile making etc. The seasonal woman unemployment in agriculture has caused a severe impact on the income of laborers, family expenditure, their savings and debt position. It also caused migration of laborers to other activities and other places. The women laborers had some suggestions of their own to overcome the problem of unemployment.
\end{abstract}

Keywords: Women Labor in Agriculture

\section{Introduction}

Labor is one of the primary factors of production. It is considered to be important not only because it is productive but also because it activates other factors and makes them useful for production purposes. The size of labor force in a country is determined by the number of people in the age group of 15-59 years as generally children below 15 years and old people above 59 years do not participate in production activity. India's labor force consists of 498.4 million workers includes child labors (2012), growing at the rate of 2 per cent annually. Out of this 51.1 per cent workers are employed in agriculture as cultivators and laborers (2012). Agricultural laborers, mostly landless constitute the poorest segment of the Indian agricultural population. They belong to the economically backward and oppressed section of the society. They mainly belong to the scheduled castes and other backward communities. They are basically unskilled and unorganized and work in farms of prosperous big farmers as casual workers on wages for a larger part of the year. One of the most disquieting features of the rural economy of India during the past several decades has been its constantly increasing trend in the number of landless laborers. Factors like rapid growth of population, law of inheritance, rise in cost of agricultural inputs and decline in small scale industries have been responsible for this increase. The phenomenon of under employment, under development and surplus population are simultaneously manifested in the daily lives and living of agricultural laborers.

\section{Materials and Methods}

The present study was conducted in Allahabad district of Uttar Pradesh during 2013-2014.

The methodology followed in conducting this research is furnished under the following headings:

1. Description of the study area

2. Sampling procedure

3. Nature and sources of data

4. Analytical techniques employed

Allahabad district was purposively selected for the study as it is the major agricultural district in the state and more than 40 per cent of the total women workforce is employed in agriculture. Chaka block was selected purposively for the study. This block has 49 panchayats and 97 villages in total. Six villages were selected randomly for the study and in each village five women agricultural laborers were selected. 


\section{International Journal of Science and Research (IJSR)}

ISSN (Online): 2319-7064

Index Copernicus Value (2013): 6.14 | Impact Factor (2015): 6.391

\section{Results and Discussion}

The results obtained are presented in this chapter under the following headings.

1. Extent of women unemployment in agriculture and the alternative sources of Employment.

2. Impact of seasonal woman unemployment in agriculture

3. Suggestions of women laborers to overcome the problem of unemployment during off season.

\section{Extent of Women Unemployment in Agriculture and the Alternative Sources of Employment}

The extent of unemployment of women laborers is given in Table 1.1.

\section{Kharif season}

During kharif season the women laborers were unemployed for 64.38 days. The unemployed days were maximum during August (25.68 days) and July (20.52 days), which together accounted for 71.76 per cent of the total unemployed days in the season.

\section{Rabi season}

During Rabi season the women laborers were unemployed for 68.09 days. The unemployment days were maximum during the months of December (25.78 days) and November (19.91 days) which accounted for 67.10 per cent of the total unemployed days in the season.

\section{Zaid season}

This is the offseason for agriculture in the study area. The women labors were unemployed for 110.04 days in this season. They were unemployed for 27.5 days in February, for 26.33 days in March, for 25.21 days in April and for 31 days in May.

Table 1.1: Season Wise Unemployment of Women Laborers in Agriculture

\begin{tabular}{|c|c|c|}
\hline \multirow{2}{*}{ Season } & \multicolumn{2}{|c|}{ Unemployment days per worker } \\
\cline { 2 - 3 } & Days & Percentage \\
\hline Kharif & 64.38 & 26.55 \\
\hline Rabi & 68.09 & 28.08 \\
\hline Zaid & 110.04 & 45.37 \\
\hline Total & 242.51 & 100 \\
\hline
\end{tabular}

\subsection{Alternative Sources of Employment for Women} Laborers in Agriculture

Because of absence of irrigation facilities in the study region no crops were raised during Zaid season. It was off season for agricultural activities and women laborers could not find any job in agriculture during this season. As a result the women laborers had to find alternate sources of employment (Table 1.2). Among the 30 sample laborers, 27 laborers got involved in other activities during off season. The laborers also worked as domestic servants. About 10 laborers were involved in this work. They worked for 2090 days and the wage rate was Rs.65-70 per day. The laborers also worked in construction of buildings. They worked for 30-60 days and earned Rs.120 per day as wages. The laborers also got employment in agriculture in neighboring villages and neighboring districts. In the months of February they went for harvesting, for about 15 days to the neighboring villages or neighboring districts and earned wages at the rate of Rs. 100 per day. About 3 laborers were involved in this activity. Some of the laborers got employment in fence making for 25 days at a wage rate of Rs.100 per day.

Table 1.2: Alternative Sources of Employment for Women Laborers in Agriculture

\begin{tabular}{|c|c|c|c|c|c|}
\hline No. & Sources & $\begin{array}{c}\text { No. of laborers } \\
\text { involved }\end{array}$ & Months & $\begin{array}{c}\text { Average No. of } \\
\text { days }\end{array}$ & $\begin{array}{c}\text { Wage rate (Rs. } \\
\text { Per day) }\end{array}$ \\
\hline 1 & Domestic work & 10 & Feb, Mar, April & $20-90$ & $50-60$ \\
\hline 2 & Construction & 12 & Feb, March & $30-60$ & 120 \\
\hline 3 & Fence making & 2 & Feb & 25 & 100 \\
\hline 4 & Harvesting in nearby villages & 3 & Feb & 30 & 100 \\
\hline \multicolumn{2}{|r|}{ Labors not moved to other jobs } & 27 & & & \\
\hline \multicolumn{2}{|r|}{ Total Laborers } & 3 & & & \\
\hline
\end{tabular}

\section{Impact of Seasonal Women Unemployment in Agriculture}

The impact of seasonal woman unemployment in agriculture on the income of the laborers, their family consumption expenditure, their savings and debt position and their migratory behavior is presented in Table 2.1 .

\subsection{Impact on Income and Expenditure}

It is evident from the Table 2.1 that during kharif and rabi season the laborers got on an average Rs.11000-12000 as income.
But during Zaid they received only Rs.1000-1200 as income from wage earnings in agriculture and Rs.3550 from other sources of employment. Altogether the laborers received on an average Rs.4750 as income in Zaid which was 56.8 per cent less compared to the average income in kharif and rabi. The expenditure on food and non-food items also decreased during Zaid season as compared to the average expenditure of kharif and rabi season. The expenditure on food item was on an average Rs.8010 during kharif and rabi. It reduced by 10.58 per cent during Zaid (Rs.7162). The expenditure on non-food items also decreased from Rs.5233 to Rs.4313. The change was 17.58 per cent. 


\section{International Journal of Science and Research (IJSR) \\ ISSN (Online): 2319-7064}

Index Copernicus Value (2013): 6.14 | Impact Factor (2015): 6.391

\subsection{Impact on Savings and debt position}

It is evident from Table 2.1 that the savings of laborers reduced from Rs.980 on an average in kharif and rabi to Rs.420 in Zaid season. The decrease was 57 per cent. The debt position of laborers also worsened in Zaid season. The average debt amount was Rs.1730 in kharif and rabi. It increased by 45.9 per cent in Zaid (Rs.3200).

Table 2.1: Impact of Seasonal Unemployment of Woman Labor in Agriculture

\begin{tabular}{|c|c|c|c|c|}
\hline No. & Variable (Average) & Kharif \& Rabi (Rs.) & Zaid (Rs.) & $\begin{array}{c}\text { Percentage change } \\
\text { No. }\end{array}$ \\
\hline 1 & Income (Wage earnings) & 11000 & 4750 & -56.8 \\
\hline 2 & Food Items & 8010 & 7162 & -10.58 \\
\hline 3 & Non food Items & 5233 & 4313 & -17.58 \\
\hline 4 & Savings & 980 & 420 & -57 \\
\hline 5 & Debt position & 1730 & 3200 & 45.9 \\
\hline
\end{tabular}

\section{Suggestions of Women Laborers to Overcome the Problem of Unemployment during Off Season}

The women laborers had some suggestions of their own to overcome the problem of unemployment (Table 3.1). Some laborers suggested that they should be given training in entrepreneurial activities like mushroom cultivation and food processing.
They also opined that technical knowledge gained through training will help them in gaining more wages. They also suggested that they should be given loans from banks for purchasing poultry birds and livestock without many formalities. Some suggested that instead of 40 days, 100 days assured employment should be provided under NREGS program. Some laborers suggested that the increase in existing wage rate can be of great help to them. About 4 laborers did not have any suggestion.

Table 3.1: Suggestions of Women Laborers to Overcome the Problem of Unemployment

\begin{tabular}{|c|c|c|c|}
\hline No. & $\begin{array}{c}\text { Suggestions offering suggestion } \\
\text { laborers }\end{array}$ & Percentage \\
\hline 1 & $\begin{array}{c}\text { Employment guarantee programs like NREGS should be implemented properly to } \\
\text { assure 100 days of work in a year }\end{array}$ & 5 & 16.6 \\
\hline 2 & $\begin{array}{c}\text { SHG activities should be enhanced and training for developing entrepreneurial skills } \\
\text { should be provided }\end{array}$ & 2 & 6.6 \\
\hline 3 & $\begin{array}{c}\text { Training should be given for skill improvement in the use of new technologies in } \\
\text { agriculture }\end{array}$ & 3 & 10 \\
\hline 4 & Wage rate should be increased so as to increase savings and reduce debt & 9 & 30 \\
\hline 5 & Loan should be provided free of interest to buy poultry and livestock etc. & 7 & 23.3 \\
\hline 6 & No suggestions & 4 & 13.3 \\
\hline
\end{tabular}

\section{Conclusion}

1. It is found that the women laborers got employment in agriculture for only one third of the total days in a year. The rest of the days they are unemployed.

2. The women laborers are found to be involved in only specific crops and specific activities in agriculture. They are not involved in any mechanical operations due to their lack of skill and as a result they are not getting employment for more number of days.

3. In the study area Zaid season is the off season in agriculture as the fields are left fallow due to lack of irrigation facilities. Women laborers are unemployed for most of the days. Some laborers were involved in employment guarantee programs and also other non agricultural activities, but only for a few days.

4. The seasonal unemployment of women laborers has severe negative impact on their income, consumption expenditure and savings. The debt position of the laborers also worsened.
5. The women laborers had many suggestions to overcome the problem of unemployment during off season like proper implementation of employment guarantee programs, higher wages in agriculture, training to improve skill and for starting entrepreneurship activities and provide loans without much formalities.

\section{References}

[1] Badiger, A.G., 1999, Participation of women in comparison with men in agriculture and allied activities. M.H.Sc. Thesis, Univ. Agric. Sci. Dharwad.

[2] Beohar, B.B., Sarawgi, A.K. and Chaudhari, A.K., 1999, Women's contribution in paddy cultivation: A case study of a village of Chhatisgarh region of Madhya Pradesh. Indian J.Agric. Econ., 54(3): 323324.

[3] Bhalla, S., 1993, The dynamics of wage determination and employment generation in Indian agriculture. Indian J. Agric. Econ., 48(3): 448-470.

[4] Birari, K.S., Nawadkar, D.S. and Mali, B.K., 1999, Employment pattern of women with special reference to agriculture in Maharashtra. Indian J. Agric. Econ., 54(3): 314

[5] Bora, L., Hazarika, P., Borgohain A. and 


\section{International Journal of Science and Research (IJSR) \\ ISSN (Online): 2319-7064}

Index Copernicus Value (2013): 6.14 | Impact Factor (2015): 6.391

Hazarika, M., 2000, Role performance of farm women in animal husbandry practices in Arunachal Pradesh. Indian J. Soc. Res., 41(1): 71-76.

[6] Boserup, E., 1970a, Economic change and roles of women. In Persistent Inequalities: Women and World Development. Ed. Irene Tinker, Oxford University Press, New York.

[7] Boserup, E., 1970b, Women's role in economic development. St. Martin's Press, New York.

[8] Bryceson, D.F., 2002, Multiplex livelihoods in rural Africa: Recasting the terms and conditions of gainful employment. The J. Mod. African Stud., 40(1):

[9] Charulatha, Verma, Vinita, K.K. and Verma, K.S., 1990, Intergender involvement in farm, home and dairy operations. J. Rural Dev., 20(2): 184-189.

[10] Chauhan, A.K. and Sirohi, S., 1999, Women participation in dairying: Experiences of intensive cattle development programme in Haryana. Indian $\mathbf{J}$. Agric. Econ., 54(3): 309.

[11] Chauhan, S.K., 1999, Women participation in tribal economy. Indian J. Agric. Econ., 54(3):320.

[12] Chawhan, S.K. and Oberoi, R.C., 1990, Role of tribal women in farm operations. Indian J.Home Sci., 20(2): 33-36.

[13] Chawla, J.S., 1999, Changing education cum employment status of female laborers in rural areas of district Amritsar (Punjab). Indian J. Agric. Econ., 54(3): 319.

[14] Dahiya, P.S., Saraswat, S.P. and Sharma, A,. 1999, Participation of women vis-à-vis men in labor force in farm and non-farm sectors in Himachal Pradesh. Indian J. Agric. Econ., 54(3): 325-326.

[15] Darley, J. and Shanmugaratnam, N., 1994, Vanishing paddy lands: Implications for food security and self-reliance. In Proceedings of the Sixth Kerala Science Congress. Thiruvanthapuram, January, pp.440442.

[16] Deshpande, R.S. and Khalil Shah, 2007, Agrarian distress and agricultural labor. The Indian J.Lab. Econ., 50(2): 257-272.

[17] Dhillon, M.K., Singh, H., Sidhu, M. and Gill J., 2007, Involvement of farm women in agricultural and allied activities - factors associated and constraints faced. Indian J. Soc. Res., 48(3): 221-227

Volume 5 Issue 6, June 2016 www.ijsr.net 